\title{
TSHR Gene Mutation
}

National Cancer Institute

\section{Source}

National Cancer Institute. TSHR Gene Mutation. NCI Thesaurus. Code C131021.

A change in the nucleotide sequence of the TSHR gene. 